Original Contribution

\title{
BLOOD PLASMA BIOCHEMICAL PARAMETERS OF CAPTIVE BLACK-NECKED PHEASANT (PHASIANUS COLCHICUS), GRAY PARTRIDGE (PERDIX PERDIX) AND CHUKAR PARTRIDGE (ALECTORIS CHUKAR) OF BOTH SEXES IN BULGARIA
}

\author{
S. Nikolov*, D. Kanakov \\ Department Internal Non-infectious Diseases, Faculty of Veterinary Medicine, Trakia University, \\ Stara Zagora, Bulgaria
}

\begin{abstract}
In the study, 36 ( $\mathrm{n}=12$ by species, $\mathrm{n}=6$ by sex) blood samples were taken from a captive, adult, clinically healthy, Black-necked pheasants or Southern Caucasus pheasants (Phasianus col. colchicus), Gray partridge (Perdix perdix), and Chukar partridge (Alectoris chukar) for plasma biochemical analyses. The investigated plasma biochemical parameters were Creatinine, Uric acid, Aspartate aminotransferase (AST), and Alanine aminotransferase (ALT). Significant differences $(\mathrm{P}<0.05)$ among both sexes were found in the activity of ALT in Black-necked pheasants. Creatinine levels are relatively close in value between the sexes in all three species, slightly higher in males. Uric acid values in male birds are much higher than in female game birds in all three species. AST and ALT activities in male pheasants were higher when compared to the females, while the trend was reversed in sex at Gray partridges.
\end{abstract}

Key words: Plasma biochemistry values, plasma blood analysis, pheasants, Gray partridge, Chukar, game birds.

\section{INTRODUCTION}

One of the most common game birds in Europe and Asia are Black-necked pheasants or Southern Caucasus pheasants (Phasianus col. colchicus), Gray partridge (Perdix perdix) and Chukar partridge (Alectoris chukar) from the order Galliformes, family Phasianidae. They are very widespread as feathered game and are very often used for hunting $(1,2)$. Over the recent years, the industrial pheasant farms worldwide were developed as a new agricultural activity with the purpose of producing more meat and therefore the pheasant population has reached a new peak nowadays $(3,4)$. Despite the fact that plasma biochemistry analyses are significantly important and widely used in the diagnostic of different illnesses in several birds, a very limited amount of information exists for pheasants,

*Correspondence to: Slavko Nikolov Department of Internal Non-infectious Diseases, Faculty of Veterinary Medicine; Trakia University, Students' Campus 6015 Stara Zagora, Bulgaria

GSM: +359897880597e-mail:

slavko92@outlook.com partridges and chukars $(5,6)$. Some studies have researched the biochemical parameters in pheasants $(7,8)$ but the values of plasma chemistry parameters in partridges and chukars are still too insufficient $(9,10)$. Because of that, precise and useful biochemical analyses are extremely important and needed. Generally, blood test can be executed for several reasons as a screening procedure to evaluate overall health $(11,12)$. Since the clinical signs of illness in birds are frequently very slight, clinical chemistry is needed to assess cellular damage $(13,14)$.

\section{MATERIALS AND METHODS}

Game birds were allocated in breeding aviaries. The birds were nourished with a patent pellet formulated for pheasants (HLTopMix OOD Company, Bulgaria) ad libitum and had access to clear water constantly. The adult animals were 52-54 week-old in the reproduction season: Black-necked pheasants allocated in families with one male and seven females; Gray partridges in pair; Chukars in families with one male and four females. All 
NIKOLOV S., et al.

birds were vaccinated against Newcastle disease virus and were treated against parasites. The blood samples were gathered from the ulnar wing vein (vena cutanea ulnaris superficialis) from 36 adult pheasants, partridges and chukars: ( 12 by species; $n=6$ by sex). Approximately $0.5 \mathrm{ml}$ whole blood was taken from each bird and instantly put into blood collection tubes that contained heparin. Samples were processed in 1-3 hours after the collection. The plasma biochemical parameters: Creatinine ( $\mu \mathrm{mol} / \mathrm{l})$, Uric acid $(\mu \mathrm{mol} / 1)$, Aspartate aminotransferase (AST) (U/l) and Alanine aminotransferase (ALT) (U/l) were measured using a standard automatic biochemical analyser (BS-120, Mindray, China). All birds were selected randomly from breeding aviaries. We got Permission to use animals in experiments №280 aviary-bred wild birds issued by Bulgarian food safety agency. The data were processed with IBM SPSS Statistics (SPSSInc., 2019, SPSS Reference Guide 26 SPSS, Chicago, USA) using descriptive statistics with frequency distribution tables. Male and female birds were analyzed apart from each other, as sex may affect the reliability of the study. All values were expressed as mean \pm with standard error and $\mathrm{P} \leq 0.05$ was determined as statistically important.

\section{RESULTS}

The average values of selected plasma biochemical parameters for adult male and female Black-necked pheasants were determined (Table 1). Major differences in plasma ALT $29.50 \pm 1.98$ were observed in both men and women. The rest blood parameters creatinine, uric acid and AST did not show significant differences between males and females. The mean values of selected plasma biochemical parameters for adult male and female Gray partridges were determined (Table 2). The general biochemical blood values including Creatinine, Uric acid, AST and ALT values were $56.17 \pm 1.16,548.67 \pm$ 55.64, 411.42 \pm 41.84 and $31.92 \pm 2.63$, respectively. All these parameters between adult male and female Gray partridges were no significant $(\mathrm{p}>0.05)$.

Table 1. Plasma biochemical parameters for male and female Black-necked pheasants $(n=12)$ in captivity in Bulgaria

\begin{tabular}{|c|c|c|c|}
\hline Parameters & $\begin{array}{c}\text { Male (n= 6) } \\
\text { Mean } \pm \text { SE (Min- } \\
\text { Max) }\end{array}$ & $\begin{array}{c}\text { Female (n= 6) } \\
\text { Mean } \pm \text { SE (Min- } \\
\text { Max) }\end{array}$ & P-value \\
\hline Creatinine ( $\boldsymbol{\mu m o l} / \mathbf{l})$ & $\begin{array}{c}54.00 \pm 2.42 \\
(48.00-61.00)\end{array}$ & $\begin{array}{c}53.00 \pm 2.00 \\
(48.00-62.00)\end{array}$ & $1.00^{\mathrm{a}}$ \\
\hline Uric acid ( $\boldsymbol{\mu m o l} / \mathbf{l})$ & $241.00 \pm 39.97$ & $208.50 \pm 38.95$ & $0.64^{\mathrm{a}}$ \\
& $(136.00-394.00)$ & $(114.00-388.00)$ & \\
\hline AST (U/l) & $394.33 \pm 9.13$ & $381.50 \pm 8.64$ & $1.00^{\mathrm{a}}$ \\
& $(359.00-418.00)$ & $(355.00-402.00)$ & \\
\hline ALT (U/I) & $31.33 \pm 3.59$ & $27.67 \pm 1.72$ & $0.005^{\mathrm{b}}$ \\
& $(23.00-48.00)$ & $(22.00-33.00)$ & \\
\hline
\end{tabular}

${ }^{\mathrm{a}}=$ Non-significant $(\mathrm{P}>0.05) ;{ }^{\mathrm{b}}=$ Significant $(\mathrm{P}<0.05) ; \mathrm{SE}=$ Standard error

Table 2 Plasma biochemical parameters for male and female Gray partridges $(n=12)$ in captivity in Bulgaria

\begin{tabular}{|c|c|c|c|}
\hline Parameters & $\begin{array}{c}\text { Male }(\mathbf{n}=6) \\
\text { Mean } \pm \text { SE (Min- } \\
\text { Max) }\end{array}$ & $\begin{array}{c}\text { Female }(\mathbf{n}=6) \\
\text { Mean } \pm \text { SE (Min- } \\
\text { Max) }\end{array}$ & P-value \\
\hline Creatinine ( $\boldsymbol{\mu m o l} / \mathbf{l})$ & $56.33 \pm 2.06$ & $56.00 \pm 1.29$ & $0.15^{\mathrm{a}}$ \\
& $(51.00-65.00)$ & $(53.00-62.00)$ & \\
\hline Uric acid ( $\boldsymbol{\mu m o l} / \mathbf{l})$ & $635.33 \pm 37.45$ & $462 \pm 95.99$ & $0.30^{\mathrm{a}}$ \\
& $(536.00-739.00)$ & $(157.00-743.00)$ & \\
\hline AST (U/l) & $383.67 \pm 74.63$ & $439.17 \pm 42.73$ & $0.58^{\mathrm{a}}$ \\
& $(145.00-528.00)$ & $(317.00-557.00)$ & \\
\hline ALT (U/l) & $28.50 \pm 3.490$ & $35.33 \pm 3.68$ & $0.98^{\mathrm{a}}$ \\
& $(22.00-45.00)$ & $(22.00-47.00)$ & \\
\hline
\end{tabular}

${ }^{\mathrm{a}}=$ Non-significant $(\mathrm{P}>0.05){ }^{\mathrm{b}}=$ Significant $(\mathrm{P}<0.05) ; \mathrm{SE}=$ Standard error 
The mean values of selected plasma biochemical parameters for adult Chukar birds were determined (Table 3). The overall biochemical blood values including Creatinine, Uric acid, AST and ALT values were $52.67 \pm$
NIKOLOV S., et al. $1.07,427.25 \pm 44.80,428.00 \pm 29.03$ and $28.08 \pm 1.98$, respectively. All these parameters between adult male and female Chukars were no significant.

Table 3. Plasma biochemical parameters for male and female Chukar partridges $(n=12)$ in captivity in Bulgaria

\begin{tabular}{|c|c|c|c|}
\hline Parameters & $\begin{array}{c}\text { Male (n= 6) } \\
\text { Mean } \pm \text { SE (Min- } \\
\text { Max) }\end{array}$ & $\begin{array}{c}\text { Female (n= 6) } \\
\text { Mean } \pm \text { SE (Min- } \\
\text { Max) }\end{array}$ & P-value \\
& $54.50 \pm 1.18$ & $50.83 \pm 1.54$ & $0.08^{\mathrm{a}}$ \\
\hline Creatinine $(\boldsymbol{\mu m o l} / \mathbf{l})$ & $(51.00-59.00)$ & $(44.00-55.00)$ & \\
\hline Uric acid ( $\boldsymbol{\mu m o l} / \mathbf{l})$ & $548.17 \pm 50.67$ & $306.33 \pm 20.37$ & $0.81^{\mathrm{a}}$ \\
& $(365.00-695.00)$ & $(245.00-363.00)$ & \\
\hline AST (U/l) & $432.50 \pm 21.01$ & $423.50 \pm 57.08$ & $0.45^{\mathrm{a}}$ \\
& $(365.00-490.00)$ & $(235.00-587.00)$ & \\
\hline ALT (U/l) & $26.17 \pm 1.74$ & $29.00 \pm 3.57$ & $0.51^{\mathrm{a}}$ \\
& $(22.00-31.00)$ & $(18.00-41.00)$ & \\
\hline
\end{tabular}

${ }^{\mathrm{a}}=$ Non-significant $(\mathrm{P}>0.05) ;{ }^{\mathrm{b}}=$ Significant $(\mathrm{P}<0.05) ; \mathrm{SE}=$ Standard error

\section{DISCUSSION}

The mean values of selected plasma biochemical parameters Creatinine, Uric acid, AST and ALT for adult male and female Black-necked pheasants were similar to Ringnecked pheasants $(15,13)$, Common pheasants (6) and pheasant hens (8):

The scores for Creatinine in males $30.94 \pm$ 4.42 and females $24.75 \pm 7.95$ were lower (13), and twice as low in males $23.249 \pm 0.13$ and females $20.24 \pm 0.11$ (15) Ring-necked pheasants from our results for male $54.00 \pm$ 2.42 and female $53.00 \pm 2.00$ Black-necked pheasants.

The levels of Uric acid in male $440.15 \pm$ 166.54 and female $541.86 \pm 172.49$ Ringnecked pheasants (13) were twice as high as $217.10 \pm 1.6$ male and $233.16 \pm 1.3$ female Ring-necked pheasants (15) and our results in males $241.00 \pm 39.97$ and females $208.50 \pm$ 38.95 Black-necked pheasants. The results in Common pheasants for Uric acid $117.60 \pm$ 87.92 were lower than our $224.75 \pm 27.05$ and other authors (6), which may be influenced by various factors - diet, season and age. However, the levels of Uric acid in laying Common pheasant hens are $240.5 \pm 28.7$ at the initial period and $296.7 \pm 23.1$ at the end of laying (8), are relatively close to the values obtained by us in Black-necked pheasant hens. The activity of AST was similar (slightly decreased) in adult male $354 \pm 61.8$ and female $335.8 \pm 88.82$ Ring-necked pheasants (13), as in our data for adult male $394.33 \pm 9.13$ and female $381.50 \pm 8.64$ Black-necked pheasants.
In contrast, AST activities were significantly lower in adult male $262 \pm 50$ and female $228 \pm$ 55 Ring-necked pheasants (15). The activity of AST in Common pheasant hens in the initial laying period was lower $293.5 \pm 20$, in contrast to its values in the final period $387.1 \pm 27.6$ (8), which was significantly close to our results in Black-necked pheasant hens.

The ALT values were recorded for male $16.5 \pm$ 5 and female $13.7 \pm 4$ Ring-necked pheasants (15) and $17.18 \pm 0.041$ for Common pheasants (6), respectively lower than our values in males $31.33 \pm 3.59$, females $27.67 \pm 1.72$ and total for both sexes $29.50 \pm 1.98$ in Black-necked pheasants, the differences were due to the fact that our data were made during the breeding period, in contrast to the other openings.

The mean values of selected plasma biochemical parameters Creatinine, Uric acid, AST and ALT for adult male and female Gray partridges and Chukar partridges were compared to the same game birds (6), Gray partridges (9), Chukar partridges (10) and Redlegged partridges (5):

Our studies of Creatinine values in male 56.33 \pm 2.06 and female $56.00 \pm 1.29$ Gray partridges were very close to the values found in our male $54.50 \pm 1.18$ and female $50.83 \pm$ 1.54 Chukar partridges. Compared to male Red-legged partridges (Alectoris rufa), Creatinine values $35.36 \pm 0.1$ were lower than our data (5). However, Creatinine in males $4019.59 \pm 15.609(45.47 \pm 15.609 \mu \mathrm{l})$ and females $6497.40 \pm 18.825(73.5 \pm 18.825 \mu \mathrm{l})$ Chukar partridges were extremely high (10). 
The data for Uric acid in Gray partridges were $608.46 \pm 418.91$ (9), which is slightly higher than our data $548.67 \pm 55.64$ for the same species, while there was a lower value for Uric acid 439,600 $\pm 166,510$ in Gray partridges (6), this may be the length of the diet and the age of game birds. Our results for Uric acid in adult male $635.33 \pm 37.45$ and female $462 \pm$ 95.99 Gray partridges, respectively, were close to our results in adult male $548.17 \pm 50.67$ and female $306.33 \pm 20.37$ Chukar partridges. The research of (6) for Uric acid values $206.50 \pm$ 56.890 at Chukar partridges were almost twice lower than our $427.25 \pm 44.80$, this difference was most likely due to the different latitude and their nutrition. However, Uric acid levels measured in male $404.46 \pm 1.9$ Red-legged partridges (Alectoris rufa) (5) were closer to our male $548.17 \pm 50.67$ Chukar partridges.

The activity of AST in Gray partridges was $287.06 \pm 1.93$ (9), which is lower activity than our $411.42 \pm 41.84$ in the same species. Our AST data for adult male $383.67 \pm 74.63$ and female $439.17 \pm 42.73$ Gray partridges were close to our values for adult male $432.50 \pm$ 21.01 and $423.50 \pm 57.08$ female Chukar partridges. The differences in AST activity in males $1091.18 \pm 4.681(18.55 \pm 4.681 \mu 1)$ and females $4022.35 \pm 50.59(68.38 \pm 50.59 \mu \mathrm{l})$ Chukar partridges were extremely high (10).

The activity of ALT in Gray partridges was $40.59 \pm 0.13$ (9), your values were $31.92 \pm 2.63$ averages, and the lowest $18.23 \pm 0.069$ (6) at birds of the same species. Our studies of ALT activity compared to male $28.50 \pm 3.490$ and female $35.33 \pm 3.68$ Gray partridges, with male $26.17 \pm 1.74$ and female $29.00 \pm 3.57$ Chukar partridges, showed an increase in Gray partridges, which is a species difference. The activity of ALT in Chukar partridges was 5.70 \pm 0.039 (6) were lower than our data $28.08 \pm 1.98$ at Chukars. While AST activity in males $782.94 \pm 3.879(13.31 \pm 3.879 \mu \mathrm{l})$ and females $815.88 \pm 3.711(3.87 \pm 3.711 \mu \mathrm{l})$ Chukar partridges were extremely high (10).

\section{CONCLUSION}

Creatinine levels are relatively close in value between the sexes in all three species, slightly higher in males. Uric acid values in male birds are much higher than in female game birds in all three species. AST and ALT activities were higher in males and lower in female pheasants, while the trend was reversed in sex at Gray partridges; the data at Chukar partridges were contradictory.

\section{ACKNOWLEDGEMENTS}

NIKOLOV S., et al.

The authors would like to express their gratitude thank the State Forestry "Stara Zagora", especially Dr. Galin Ivanov for his help in the work of game birds; Dr. Ivanka Lazarova for her help in statistical analyses; and the Clinical Laboratory at the Faculty of Veterinary Medicine for plasma blood analysis.

\section{REFERENCES}

1. Draycott, R.A.H., M.I.A. Woodburn, J.P. Carroll and R.B., Sage, Effects of spring supplementary feeding on population density and breeding success of released pheasants Phasianus colchicus in Britain. Wildlife Biology, 11: 177-182, 2005. DOI: 10.2981/09096396(2005)11[177:EOSSFO]2.0.CO;2

2. Kokoszynski, D., Z. Bernacki and A. Cisowska, Growth and development of young game pheasants (Phasianus colchicus). Archiv fur Tierzucht, 54: 83-92, 2011. DOI:10.5194/AAB-54-83-2011

3. Draycott, R.A.H., K. Pock and J.P.Carroll, Sustainable management of a wild pheasant population in Austria. Zeitschrift für Jagdwissenschaft, 48: 346-353, 2002. DOI: $10.1007 / \mathrm{BF} 02192427$

4. Kuzniacka, J. and M.Adamski, Growth rate of body weight and measurements in pheasants reared up to the 24th week of life. Archiv fur Tierzucht, 53: 360-367, 2010. DOI: 10.5194/aab-53-360-2010

5. Rodriguez, P., F. S. Tortosa, J. Millan and C. Gortazar, Plasma chemistry reference values from captive red-legged partridges (Alectoris rufa). British Poultry Science, 45(4): $\quad 565-567, \quad 2004$. DOI: 10.1080/00071660412331286271

6. Suchy, P., E. Strakova, L. Kroupa, L. Steinhauser and I. Herzig, Values of selected biochemical and mineral metabolism indicators in feathered game. Acta Veterinaria Brno, 79: S9-S12, 2010. DOI: $10.2754 / \mathrm{avb} 201079$ S9S009

7. Schmidt, E.M.S., A.C. Paulillo, E. Santin, R. Locatelli-Dittrich and E.G. Oliveira, Hematological and serum chemistry values for the ring-necked pheasant (Phasianus colchicus): variation with sex and age. International Journal of Poultry Science, 6: 137-139, 2007. DOI: 10.3923/ijps.2007.137.139

8. Hrabcaková, P., E. Voslálová, I. Bedánová, V. Pišteková, J. Chloupek and V. Vecerek, Haematological and Biochemical Parameters during the Laying Period in 
Common Pheasant Hens Housed in Enhanced Cages. The Scientific World Journal, Volume 2014, 2004. DOI: $10.1155 / 2014 / 364602$

9. Vitula, F., L. Peckova, H. Bandouchova, M. Pohanka, L. Novotny, D. Jira, J. Kral, K. Ondracek, J. Osickova, D. Zendulkova, K. Rosenbergova, F. Treml and J. Pikula, Mycoplasma gallisepticum infection in the grey partridge Perdix perdix: outbreak description, histopathology, biochemistry and antioxidant parameters. $B M C$ Veterinary Research, 7(1): 34, 2011. DOI: 10.1186/1746-6148-7-34

10.Farooq, Z., I. Baboo, M. Wajid, H. Sadia, M. Abrar, K. J. Iqbal, A. Javid and D. Hussain, Hematological and Plasma biochemical reference values in Chukar Partridge (Alectoris chukar) under captive facilities. Biologia Pakistan, 65 (II): 2019. ISSN 2313 - 206X (On-Line)

11.Harrison, G.J. and T.L. Lightfoot, Clinical Avian Medicine. Volume $1 \& 2$, Spix Publishing, Florida, 2006.
NIKOLOV S., et al.

12.Wilkinson, N., I. Dinev, W. J. Aspden, R. J. Hughes, I. Christiansen, J. Chapman, S. Gangadoo, R. J. Moore, D. Stanley, Ultrastructure of the gastro intestinal tract of healthy Japanese quail (Coturnix japonica) using light and scanning electron microscopy. Animal Nutrition, 4(4): 2018. DOI: 10.1016/j.aninu.2018.06.006

13.Nazifi, S., N. Mosleh, V.R. Ranjbar and M. Khordadmehr, Reference values of serum biochemical parameters in adult male and female ring-necked pheasants (Phasianus colchicus). Comparative Clinical Pathology, 2011. DOI: 10.1007/s00580011-1212-9

14.Dinev, I., Axial skeleton pathology in broiler chickens. World's Poultry Science Journal, 70(02): 303-308, 2014. DOI: $10.1017 / \mathrm{S} 0043933914000312$

15.Keçeci, T. and R. Çöl, Haematological and biochemical values of the blood of pheasants (Phasianus colchicus) of different ages. Turkish Journal of Veterinary and Animal Sciences, 35(3): 149-156, 2011. DOI: 10.3906/vet-0910-135 